\title{
Protocheirodon, a new genus of Characidae (Teleostei: Characiformes) with the redescription of the poorly known Protocheirodon pi
}

\author{
Richard P. Vari ${ }^{1 \dagger}$, Bruno F. Melo ${ }^{1,2}$ and Claudio Oliveira ${ }^{2}$
}

Protocheirodon, a new genus of the Characidae, is proposed to include a species previously assigned to Leptagoniates. This action is supported by molecular and morphological phylogenetic hypotheses that place Protocheirodon pi as the sister group of the remaining tribes in the Cheirodontinae versus the traditional assignment of the species to the Aphyocharacinae. The phylogenetic position of Protocheirodon is recognized as a new tribe, the Protocheirodontini. Protocheirodon pi, originally described based on a small number of specimens from a single location in the río Mamoré basin in the southwestern Amazon, is redescribed on the basis of larger series of specimens from the western and central portions of the Amazon basin.

Protocheirodon, um gênero novo de Characidae é proposto para incluir uma espécie previamente alocada em Leptagoniates. Esta decisão é suportada por hipóteses filogenéticas moleculares e morfológicas que apontam Protocheirodon pi como grupo-irmão das demais tribos de Cheirodontinae, ao invés da alocação tradicional em Aphyocharacinae. A posição filogenética de Protocheirodon é reconhecida como uma tribo nova, Protocheirodontini. Protocheirodon pi, originalmente descrito com base em poucos exemplares de uma única localidade na bacia do rio Mamoré, no sudoeste da Amazônia, é redescrito com base em grandes séries de espécimes coletados em rios das porções centrais e ocidentais da bacia do rio Amazonas.

Keywords: Aphyocharacinae, Amazon basin, Cheirodontinae, Leptagoniates, Taxonomy.

\section{Introduction}

Leptagoniates Boulenger, 1887, was originally proposed to include a single species, L. steindachneri that is characterized by a notably elongate body and lengthy anal fin. Nine decades later, Vari (1978) described a second species, $L$. pi, from a limited sample from the río Mamoré, Bolivia. That author provisionally assigned the new species to Leptagoniates given its possession of tricuspidate dentition, an elongate body, and a long anal fin - the traditional features proposed as diagnostic for Leptagoniates. Leptagoniates pi is striking and unique in the Characiformes in possessing a distinctive, externally apparent, three-chambered swimblader in the form of the Greek letter pi $(\pi)$ that facilitates its ready identification.

Subsequent decades saw few studies involving the taxonomy and systematics of Leptagoniates and reputed related genera (e.g., Paragoniates, Phenagoniates, and Xenagoniates) other than for reports of various species in summary checklists. In the case of Leptagoniates pi there were also citations of the species from various portions of the Amazon basin, some distant from the type locality (e.g., Bogotá-Gregory \& Maldonado-Ocampo, 2006; Duarte et al., 2010; Lima et al., 2013).

Recent morphological and molecular phylogenies addressed the questions of the monophyly and composition of both the Aphyocharacinae (Oliveira et al., 2011; Tagliacollo et al., 2012) and Cheirodontinae (Malabarba, 1998; Mariguela et al., 2013). Particularly noteworthy relative to Leptagoniates is the evidence from the two molecularbased analyses (Tagliacollo et al., 2012; Mariguela et al., 2013) that agree on the non-monophyly of the genus as delimited in recent decades. In both analyses, the type species of the genus, L. steindachneri, appears as the sister group to Xenagoniates in the Aphyocharacinae, whereas L. $p i$ is the sister to the remainder of the Cheirodontinae (Fig. 1). In order to resolve the non-monophyly of the genus, we herein transfer $L$. pi from the Leptagoniates to a new monotypic genus described herein. We also provide a comprehensive description of the $L$. $p i$ based on extensive series of specimens that originated across broad portions of the western and central portions of the Amazon basin.

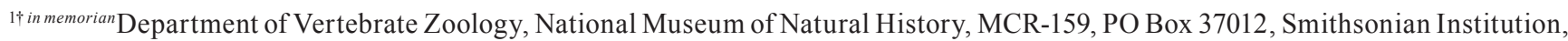
20013-7012 Washington, DC, USA. melo@ibb.unesp.br (corresponding author)

${ }^{2}$ Departamento de Morfologia, Instituto de Biociências, Universidade Estadual Paulista, Distrito Rubião Jr. s/n, 18618-970 Botucatu, SP, Brazil.claudio@ibb.unesp.br 


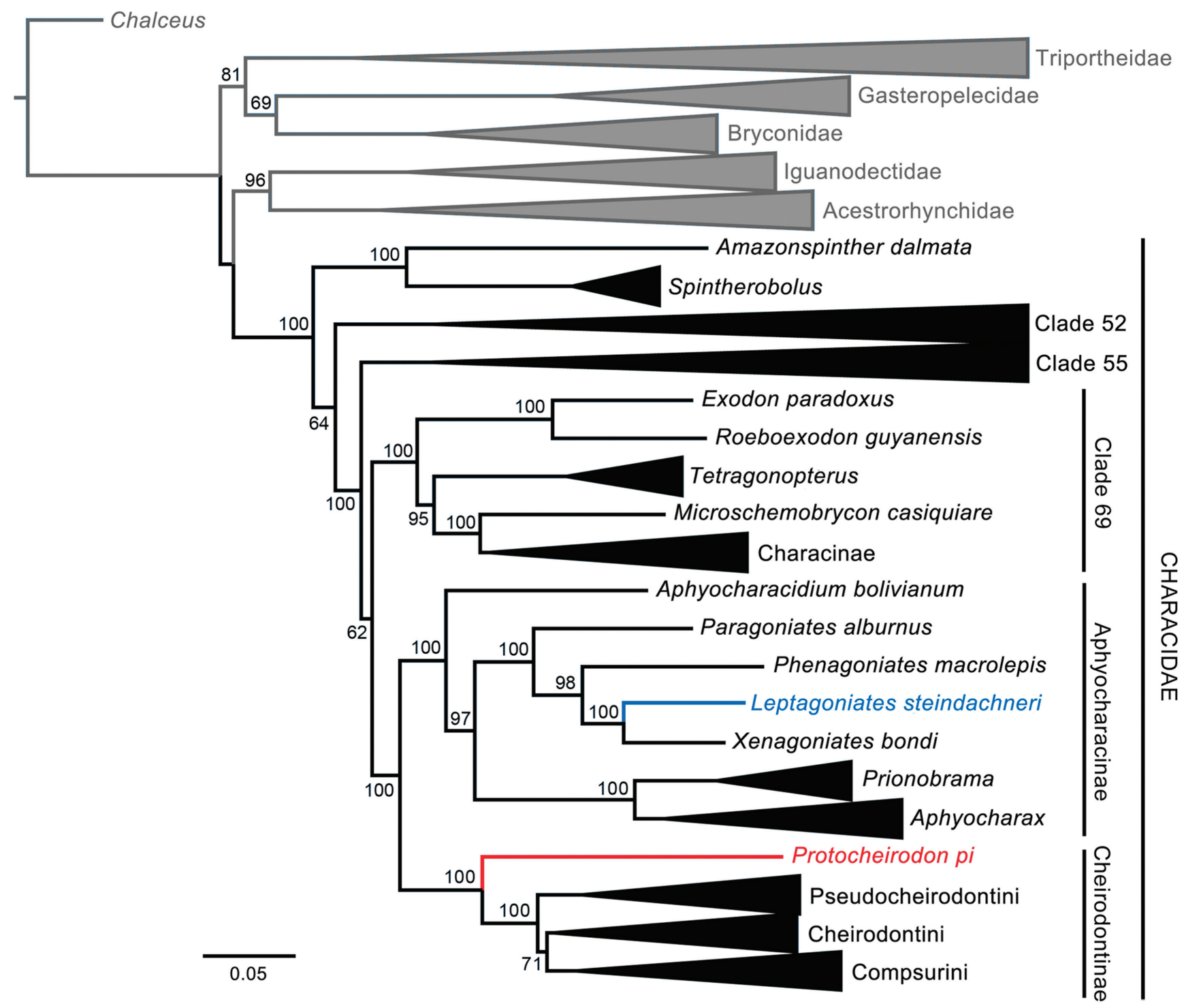

Fig. 1. Molecular phylogenetic tree of the Characidae and outgroup families (modified from Mariguela et al., 2013) showing the placement of Leptagoniates steindachneri (blue) as sister to Xenagoniates within the Aphyocharacinae and Protocheirodon pi (red) as sister to the remaining members of the Cheirodontinae.

\section{Material and Methods}

Measurements were taken point to point with a digital caliper on the left side of specimens and are expressed as a percentage of standard length (SL) or head length (HL). Osteological observations were made on cleared and stained (c\&s) specimens. Vertebral counts include the four vertebrae of the Weberian apparatus with the terminal centrum counted as one single element. Numbers of specimens with a particular meristic value are indicated in parentheses. Acronyms for the collections that house the samples that were the basis of the morphological and molecular analysis follow Sabaj Pérez (2014). Map localities were based on the vouchers whose identity was confirmed by the authors.

\section{Results}

\section{Protocheirodon, new genus}

urn:1sid:zoobank.org:act:169925E2-807B-4DC7-8AF674EFC4729EA2

Type species. Protocheirodon pi (Vari, 1978).

Diagnosis. Protocheirodon possesses the four synapomorphies proposed for the Cheirodontinae by Malabarba (1998): 1) the presence of a pseudotympanum, a hiatus in the body wall musculature lateral to at least a portion of the anterior chamber of the swimbladder; 2) the lack of a dark humeral spot; 3 ) the possession of pedunculate 
dentition; and 4) the presence of only a single row of regularly arranged premaxillary teeth. Protocheirodon differs from all other genera of the Cheirodontinae and indeed members of the Characiformes by the unique form of the swimbladder which has a smaller rotund anterior chamber and the posteriorly chamber elaborated into two vertically elongate, side by side, slightly inclined chambers. These modifications yield a unique overall pi $(\pi)$-shaped structure (Vari, 1978) (Fig. 2). This trenchant difference versus other cheirodontins is supplemented by a diagnostic combination of meristic, morphometric and details of pigmentation.

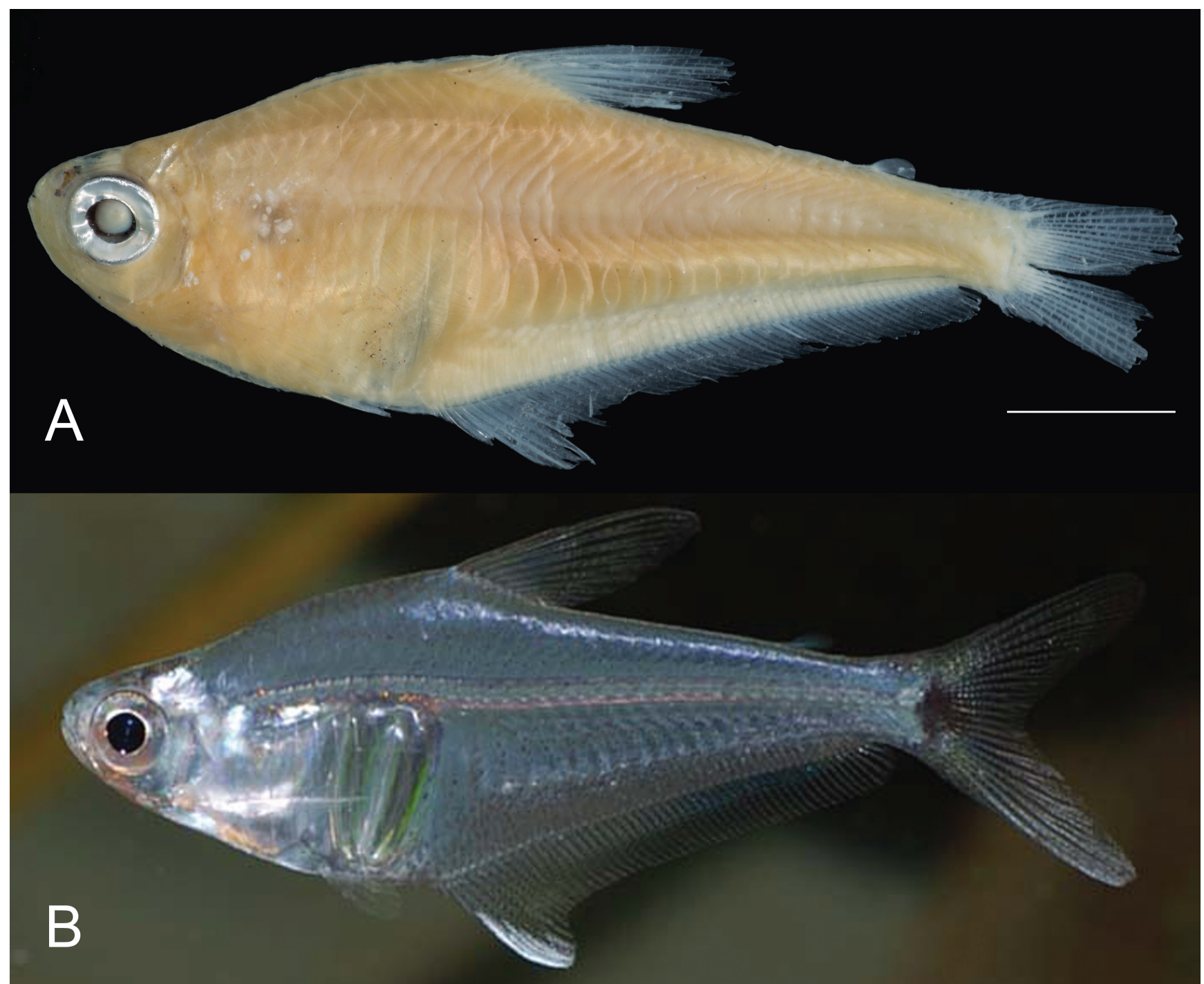

Fig. 2. Protocheirodon pi, (A) CAS 41749, $29.5 \mathrm{~mm}$ SL; Colombia, Amazonas, Isla de Santa Sofia II, ca. $20 \mathrm{mi}$ (= $32 \mathrm{~km}$ ) NW of Leticia; (B) live specimen from aquarium without locality information. Scale bar $=5$ mm. Photo credits: (A) Sandra Raredon (USNM) and (B) Martin and Peter Hoffmann.

Description. As Protocheirodon is a monotypic genus, its description corresponds to the redescription of the typespecies, Protocheirodon pi (Vari, 1978).

Etymology. Proto from Greek prōto, meaning first or earliest form of, in reference to the phylogenetic position of the species as sister to all remaining members of the Cheirodontinae, and cheirodon, an allusion to the genus Cheirodon and subfamily Cheirodontinae. Gender masculine.

\section{Protocheirodon pi (Vari, 1978)}

Leptagoniates pi Vari, 1978: 185, figs. 1-2 (original description; río Mamoré, Bolivia). -Malabarba, 1998: 229 (in phylogeny of Cheirodontinae). Lima et al., 2003: 144 (in list of incertae sedis species in Characidae). -BogotáGregory \& Maldonado-Ocampo, 2006: 66 (in list of fishes in Colombian Amazon). -Maldonado-Ocampo et al., 2008: 170 (Colombia, Amazon; in checklist of freshwater fishes of Colombia). -Duarte et al., 2010: 323 (in list of fishes 
from lower rio Purus, Brazil). Ortega et al., 2010: 36 (in list of freshwater fishes of Peru). -Lima et al., 2013: 299 (in list of fishes from rio Madeira, Brazil). -Tagliacollo et al., 2012: 305 (in molecular phylogeny of Aphyocharacinae). -Mariguela et al., 2013: 29 (in molecular phylogeny of Cheirodontinae).

Diagnosis. As for Protocheirodon above.

Description. Summary morphometrics in Table 1. Body distinctly compressed and moderately elongate with greatest depth immediately anterior to dorsal-fin origin. Dorsal profile of head convex from margin of upper lip to vertical through anterior margin of orbit and then very slightly concave to rear of head. Predorsal profile of body straight to very slightly sigmoid. Dorsal profile strongly posteroventrally angled along dorsal-fin base and then straight and less posteroventrally angled to caudal peduncle. Ventral profile of head and body gently convex from tip of lower jaw to anal-fin origin, straight and posterodorsally angled along anal-fin base to caudal peduncle.

Table 1. Morphometric data for 24 examined specimens of Protocheirodon pi. $\mathrm{SD}=$ standard deviation. Mean and range do not include type specimens.

\begin{tabular}{|c|c|c|c|}
\hline & Mean & Range & SD \\
\hline Standard length $(\mathrm{mm})$ & - & $18.8-35.6$ & - \\
\hline \multicolumn{4}{|c|}{ Percentage of standard length } \\
\hline Greatest body depth & 25.6 & $23.9-27.3$ & 1.7 \\
\hline Snout to dorsal-fin origin & 53.5 & 49.6-56.9 & 1.9 \\
\hline Snout to pectoral-fin origin & 22.8 & $18.2-27.3$ & 1.3 \\
\hline Snout to pelvic-fin origin & 36.8 & $34.3-38.7$ & 2.0 \\
\hline Snout to anal-fin origin & 33.2 & $29.7-35.2$ & 2.1 \\
\hline Snout to anus & 32.9 & $28.7-34.4$ & 2.0 \\
\hline Dorsal-fin origin to hypural joint & 55.3 & $53.3-59.0$ & 2.6 \\
\hline Caudal-peduncle depth & 18.9 & $17.8-20.2$ & 1.0 \\
\hline Pectoral-fin length & 16.0 & $7.2-19.8$ & 2.3 \\
\hline Pelvic-fin length & 7.3 & $6.9-8.4$ & 1.1 \\
\hline Dorsal-fin length & 23.4 & $21.2-25.6$ & 1.4 \\
\hline Length of base of anal fin & 56.2 & $54.5-59.9$ & 2.7 \\
\hline Head length & 19.2 & $17.9-20.2$ & 1.6 \\
\hline \multicolumn{4}{|c|}{ Percentage of head length } \\
\hline Snout length & 24.6 & $19.8-28.2$ & 2.2 \\
\hline Orbital diameter & 46.6 & $43.0-51.2$ & 2.7 \\
\hline Postorbital length & 43.3 & $37.5-46.3$ & 2.2 \\
\hline Interorbital width & 38.7 & $35.4-41.2$ & 1.9 \\
\hline
\end{tabular}

Mouth small. Maxilla distinctly posteroventrally slanted and reaching horizontal through ventral margin of orbit. Margin of non-tooth bearing portion of maxilla gently convex. Teeth in single series in each jaw with functional dentition of premaxilla and dentary followed internally by replacement tooth series. All teeth pedunculate and tricuspidate with median cusp distinctly larger. Premaxilla with seven or eight teeth. Maxilla with four or five teeth. Dentary with nine to 11 teeth. Third infraorbital falling short of horizontal arm of preopercle; fourth and fifth infraorbitals reduced to tubular ossifications at rear of orbit.

Dorsal fin long and pointed; tip of adpressed fin reaching one-half distance to adipose-fin insertion. Dorsalfin rays ii,7(18) or ii,8(1). Pectoral fin pointed with tip of fin typically extending well beyond vertical through pelvicfin insertion. Pectoral-fin rays i,11(20) or i,12(5). Pelvic fin short, reaching only one-half distance to anal-fin origin. Pelvic-fin rays i,4(3) or i,5(22). Anal fin elongate; first three rays originate from single basal pterygiophore. Third through sixth to eighth anal-fin rays longer than remaining rays and forming distinct lobe; remainder of fin margin straight. Anterior rays form distinct lobe. Anal-fin rays iii,44(4), iii,45(13), iii,46 (16), iii,47(3), or iii,48(1). Adipose fin small. Caudal fin emarginate with 11 to 13 dorsal and 7 to 9 ventral procurrent rays.

Scales thin and cycloid. Lateral line completely pored. Lateral line scales 32(1), 33(3), 34(10), 35(8), 36(9), 37(4), $38(2)$, or 39(1). Scales above lateral line to middorsal line 7 (9) or 8(13). Scales below lateral line to pelvic-fin insertion $4(21)$.

Coloration in alcohol. Ground coloration pale yellow (Fig. 2a). Concentration of dark chromatophores variably present on middle of posterior region of caudal peduncle and base of middle caudal-fin rays. Scattered dark pigmentation present on dorsal most region of body in some specimens. Fins hyaline overall, but some individuals with series of small, dark chromatophores along fin-ray margins. Region of pseudotympanum over anterior chamber of swimbladder and area overlying ventral portions of sub-chambers of posterior chamber of swimbladder slightly darker; coloration function of reduction in body wall thickness rather than dark pigmentation.

Coloration in life. Head and abdominal region silvery with guanine most prominent on dorsolateral and lateral surfaces of head and over intestinal tract (Fig. 2b). Vertical sub-chambers of posterior portion of swimbladder obvious through translucent body wall and covered by guanine; region with very slight greenish tint in some specimens. Body translucent with vertebral column and myomeres margins obvious. Some individuals with narrow dark line apparent above vertebral column and with myomeres outlined with variably intense dark chromatophores. Patch of dark chromatophores variably present on middle of posterior of caudal peduncle and base of middle caudalfin rays. Median fins most often hyaline, but overall darker specimens with fin ray margins outlined by series of dark chromatophores. Distal portion of lobe at anterior of anal fin white. Pectoral and pelvic fins hyaline or with few dark chromatophores along fin-ray margins. Ventral margin of caudal fin with elongate, very narrow white stripe in some individuals. 
Ecology. Samples of Protocheirodon pi originated in marginal areas of rivers and streams, often over sandy substrates and in still backwaters. Sexual dimorphism was not observed.

Distribution. Protocheirodon pi is widely distributed in the major river systems of the central and western portions of the Amazon basin (Fig. 3) including the AmazonasSolimões, Purus, Madeira and Ucayali rivers (see also Remarks below).

Remarks. One examined lot (USNM 191640) reputedly originated in the rio Araguaia, near Aruanã, Goiás, Brazil $\left(14^{\circ} 58^{\prime} \mathrm{S} 51^{\circ} 24^{\prime} \mathrm{W}\right)$. This location is distant from the known limits of the range of Protocheirodon and would represent the only record of the genus from the rio Tocantins basin, let alone in its upper reaches. This sample was collected during wide ranging sampling efforts focused on aquarium fishes and some portions of material have questionable locality data (S. H. Weitzman, pers. comm.).

Conservation status. Given the broad distribution throughout central and western Amazon (Fig. 3) and the absence of significant threats over many sampled localities, Protocheirodon pi should be categorized as Least Concern (LC) under the International Union for Conservation of Nature (IUCN) categories and criteria (IUCN Standards and Petitions Subcommittee, 2014).

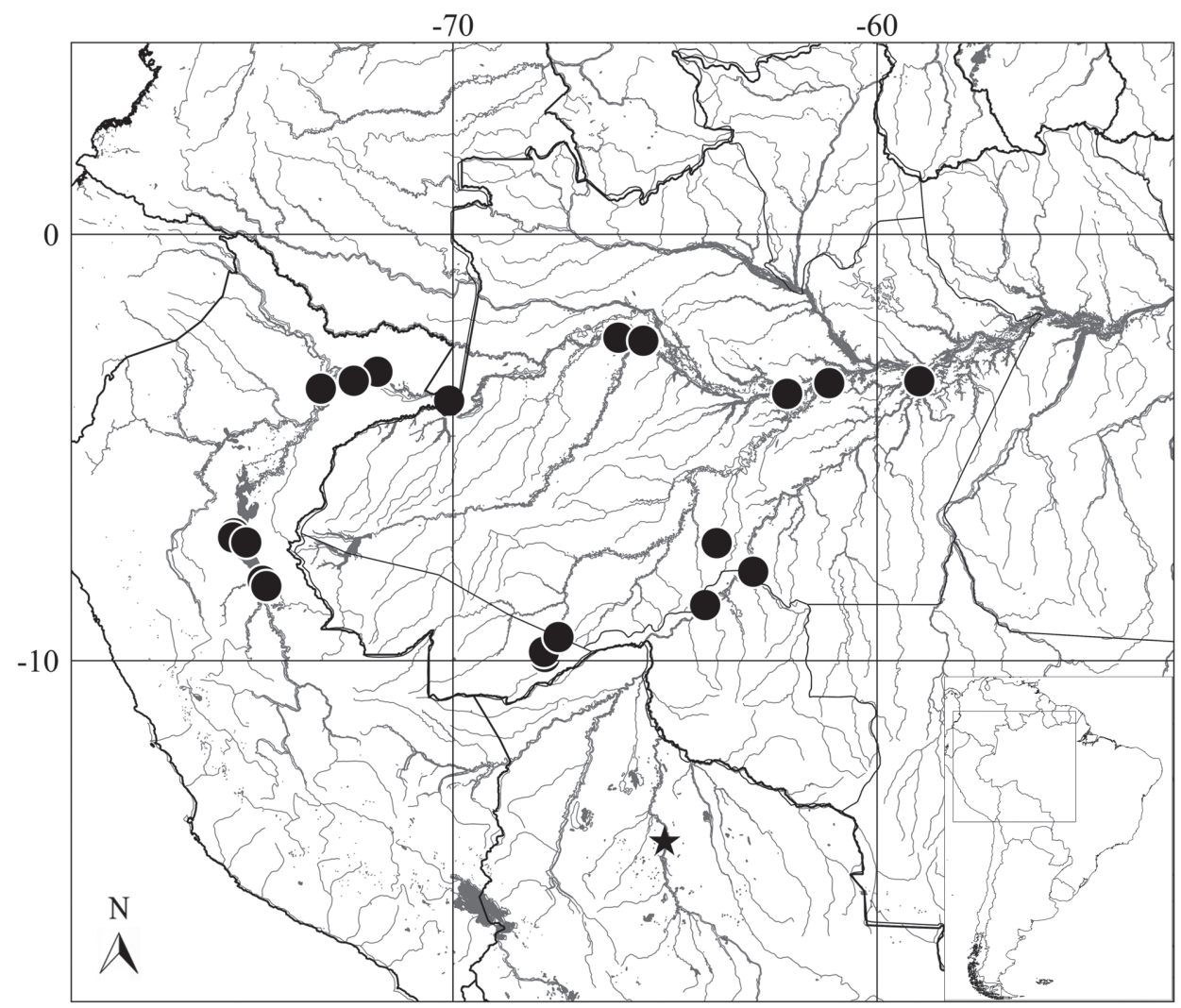

Fig. 3. Central and western Amazon basin showing the distribution of Protocheirodon pi. Star indicates the type locality. Black lines represent country boundaries.

Material examined. Holotype. AMNH 35952, $29.2 \mathrm{~mm} \mathrm{SL}$, Bolivia, Departamento Beni, río Mamoré, $10 \mathrm{~km}$ W of San Pedro, lagoons communicating with river, approximately 14²1'01.7"S 6459'40"W, 17 Sep 1965, S. Anderson. Paratypes. AMNH 35953, 3, 27.2-31.0 mm SL; BMNH 1977.6.9.138, 1, $28.0 \mathrm{~mm}$ SL, collected with holotype. Non-types. Brazil: LBP 10565, 10, 29.3-32.2 mm SL, Acre, Rio Branco, rio Acre-Purus, 1003'28.6”S 6751'25.6”W. LBP 15095, 1, 30.0 mm SL, Acre, Rio Branco, rio Acre-Purus, 0956'16.6”'S 6752'43.6”W. LBP 18603, 4, 27.2-34.2 mm SL, Acre, Porto Acre, rio Acre-Purus, 09³5'24.6”'S 67³1'53.4”W. MZUSP 49643, 2, 27.7-30.8 mm SL, Acre, Seringal do Acre, rio Purus. MZUSP 12400, 5, 20.7-27.6 mm SL, Amazonas, Boca do Paraná do Catito, rio Solimões, below mouth of rio Juruá, 02³8'S 64² ${ }^{\circ}$ 'W. MZUSP 17427 , 2, 20.6-27.0 mm SL, rio Solimões, at Jacaré, near Fonte Boa, 02³0'59.9”S 6606'0.2”W. MZUSP 9604, 2, 18.9-23.3 mm SL, Amazonas, Boca do Lago Pereira, rio Solimões, in front of Codajás, 0350'60"S 62³'60"W. MZUSP 12399, 2, 22.2-23.6 mm SL, Amazonas, Fonte Boa, 02³0'59.9”S 6606'0.2”W. MZUSP 57224, 1, 19.3 mm SL, Amazonas, rio Solimões, below rio Purus, 03³3'23.7" 61'9'52.1”W. MZUSP 56150, 4, 21.9-24.1 mm SL, Amazonas, rio Solimões, $34.3 \mathrm{~km}$ below Juruá, 03³4'52.2”S 66²5'37.7'W. MZUSP 56142, 2, 23.9-25.2 mm SL, Amazonas, rio Solimões, $31.5 \mathrm{~km}$ below Juruá, 02³9'50”S 65³6’32.3”W. 
MZUSP 35619, 2, 27.5-29.4 mm SL, Amazonas, rio Madeira, Ilha do Puruzinho, $07^{\circ} 23^{\prime}$ 'S $63^{\circ} 45^{\prime} \mathrm{W}$. MZUSP 55923, 5, 24.8$27.4 \mathrm{~mm}$ SL, Amazonas, rio Madeira, $1.9 \mathrm{~km}$ below Paraná do Urucurituba, 0333'31.1"S 5855'45.4”W. MZUSP 35606, 2, 25.2-26.1 mm SL; MZUSP 98292, 1, 32,1 mm SL, Rondônia, rio Madeira, cachoeira de Santo Antônio, 08 ${ }^{\circ} 50^{\prime}$ 'S 6401'W. MZUSP 76856, 4, 19.6-21.4 mm SL, Rondônia, rio Madeira, Calama, lago do Caraparu, 0802'12.1'S 6252'33.4”W. Colombia: CAS 41749, 2, 25.7-29.5 mm SL, Amazonas, Isla de Santa Sofia II, ca. $20 \mathrm{mi}(=32 \mathrm{~km}) \mathrm{NW}$ of Leticia, large lake near shoreline. Peru: ANSP 149428, 2, 26.2-27.4 mm SL; ANSP 149430, 1, 26.2 mm SL, Loreto, vicinity of Iquitos, S of Isla Iquitos. ANSP 149429, 2, 25.8-29.8 mm SL, Ucayali, Inahuaya District. ANSP 150120, 4, 28.4-35.6 mm SL, río Ambiyacu. ANSP 178120, 1, 31.7 mm SL, Loreto, Maynas, río Napo, upstream of río Maza, town of Mazan. CAS 41748, 1, 26.2 mm SL, Loreto, Caño del Chancho, near Pebas. CAS 70650, 5, 18.8-25.2 mm SL, Ucayali, sandbars of río Bajo Ucayali, at Inhehuaya. FMNH 84201, 4, 23.6-28.7 mm SL, Ucayali, sand beach across from Pucallpa. MZUSP 26387, 4, 28.9-30.0 mm SL, Ucayali, Pucallpa, río Ucayali. SU 58309, 1, $24.3 \mathrm{~mm}$ SL, Ucayali, río Ucayali, sandbanks near Orellana, small town on right bank below Contamana. USNM 280399, 14, 19.4-22.9 mm SL, Ucayali, Distrito Coronel Portillo, side caño off Caño Yarinacocha. Questionable locality: USNM 191640, 2, 29.1-31.2 mm SL, Brazil, Goiás, rio Araguaia, near Aruanã, $14^{\circ} 58^{\prime}$ S $51^{\circ} 24^{\prime} \mathrm{W}$.

\section{Discussion}

In his morphological analysis, Mirande (2010) redefined the Aphyocharacinae to include eight genera: Aphyocharax, Inpaichthys, Leptagoniates, Paragoniates, Phenagoniates, Prionobrama, Rachoviscus, and Xenagoniates. Leptagoniates was provisionally included in the Aphyocharacinae based on the overall similarity of the type species of the genus, L. steindachneri, to Xenagoniates which was included in Mirande's analysis. Mirande (2010) proposed three synapomorphies supporting the subfamily: the synchondral articulation between the lateral ethmoid and the anterodorsal border of the orbitosphenoid; the absence or reduction of the fourth infraorbital, with that ossification, when present, bordered posteriorly by the third and fifth infraorbitals; and the possession of six or fewer branched pelvic-fin rays. Each of these synapomorphies, particularly the third is paralleled in other lineages of the Characidae. Our observations failed to reveal the first two of these synapomorphies in Protocheirodon pi and as noted the third is highly homoplastic across the Characidae. These factors in combination cast doubt as to the assignment of this species to the Aphyocharacinae.

In their study integrating morphological and molecular data, Tagliacollo et al. (2012) hypothesized an alternative composition of the Aphyocharacinae that included Aphyocharacidium, Aphyocharax, Leptagoniates steindachneri, Paragoniates, Phenagoniates, Prionobrama, and Xenagoniates but not Inpaichthys kerri, the two species of Rachoviscus or Leptagoniates pi (=Protocheirodon pi). The four latter taxa all were previously incorporated in that subfamily. This hypothesis indicates that as delimited in recent decades, Leptagoniates is polyphyletic. Tagliacollo et al. (2012) support the Aphyocharacinae of their study with a single morphological synapomorphy: the articulation of two dorsal-fin rays on the first dorsal-fin basal pterygiophore. This arrangement is present in L. steindachneri but absent in P. pi. Thus, Protocheirodon pi lacks nearly all of the morphological synapomorphies for the Aphyocharacinae proposed by Mirande (2010) and Tagliacollo et al. (2012).

Molecular phylogenies (Tagliacollo et al., 2012; Mariguela et al., 2013) conform to the morphological evidence in excluding Leptagoniates pi (=Protocheirodon pi) from the Aphyocharacinae. These analyses instead support the hypothesis that $P . p i$ is sister to all remaining species of the Cheirodontinae (Fig. 1). Analysis revealed that $P$. pi shares the four synapomorphies diagnostic for the Cheirodontinae (Malabarba, 1998; see listing of the synapomorphies in the Diagnosis of the genus). The sum of the evidence indicates that Protocheirodon is a member of the Cheirodontinae (sensu Malabarba, 1998) and the sister to all other taxa in that subfamily (Tagliacollo et al., 2012; Mariguela et al., 2013).

The expansion of the Cheirodontinae as a result of the discovery that Protocheirodon is sister to all other members of the subfamily necessitates a modification of classification of the subfamily (sensu Mariguela et al., 2013). Given the phylogenetic position of Protocheirodon, it is appropriate to recognize that lineage as a new tribe, the Protocheirodontini. The Cheirodontinae is, thus, composed of four monophyletic tribes: Protocheirodontini, Pseudocheirodontini, Cheirodontini, and Compsurini.

Comparative material examined. Acinocheirodon melanogramma: Brazil: LBP 8104, 30, 19.3-26.4 mm SL, Minas Gerais, rio São Francisco basin. Aphyocharax dentatus: Brazil: LBP 8532, 17, 40.4-71.3 mm SL, Mato Grosso, rio Paraguay basin. 'Cheirodon' stenodon: Brazil: LBP 3859, 2, 22.0-24.3 mm SL, São Paulo, rio Paraná basin. Compsura heterura: Brazil: LBP 8956, 1, 25.5 mm SL, Minas Gerais, rio São Francisco basin. Leptagoniates steindachneri: Peru: LBP 14828, 1, 57.5 mm SL, Loreto, río Ucayali basin. MZUSP 26085, 1, 48.9 mm SL, Peru, Ucayali, río Ucayali basin. Macropsobrycon xinguensis: Brazil: LBP 15745 , 3, 18.8-27.3 mm SL, Mato Grosso, rio Xingu basin. Odontostilbe paraguayensis: Brazil: LBP 3486, $29.5 \mathrm{~mm}$ SL, São Paulo, rio Paraná basin. Paragoniates alburnus: Venezuela: LBP 9208, 2, 55.9-59.7 mm SL, Guarico, río Orinoco basin. Brazil: MZUSP 42336, 6, 35.7-58.8 mm SL, Amazonas, rio Solimões basin. Phenagonates macrolepis: Venezuela: LBP 6105, 1, 23.6 $\mathrm{mm}$ SL, Zulia, lago Maracaibo basin. Prionobrama filigera: Brazil: LBP 18897, 1, 42.7 mm SL, Amazonas, rio Purus basin. Serrapinnus heterodon: Brazil: LBP 9046, 6, 26.9-30.7 mm SL, Minas Gerais, rio São Francisco basin. Xenagoniates bondi: Venezuela: MZUSP 65531, 2, 38.0-39.8 mm SL, Delta Amacuro, río Orinoco basin. 


\section{Acknowledgements}

We thank Sandra Raredon (USNM) for Fig. 2a and radiographs, Martin and Peter Hoffmann for Fig. 2b, Barbara Brown (AMNH), Mark Sabaj Pérez (ANSP), David Catania (CAS), Caleb McMahan and Susan Mochel (FMNH), and Osvaldo Oyakawa and Aléssio Datovo (MZUSP) for hospitality during visits and the loan of specimens. We also thank Fernando Carvalho (UFMS), Luiz Malabarba (UFRGS) and an anonymous reviewer for valuable suggestions on the manuscript. Support for the project was provided by the Herbert R. and Evelyn Axelrod Chair in Systematic Ichthyology, Division of Fishes, National Museum of Natural History (RPV), and FAPESP \#2011/08374-1, CNPq \#140193/2015-4 (BFM) and FAPESP \#2011/50282-7 (CO).

\section{References}

Bogotá-Gregory, J. D. \& J. A. Maldonado-Ocampo. 2006. Peces de la zona hidrogeográfica de la Amazonia, Colombia. Biota Colombiana, 7: 55-94.

Duarte, C., L. H. Rapp Py-Daniel \& C. P. Deus. 2010. Fish assemblages in two sandy beaches in lower Purus river, Amazonas, Brazil. Iheringia, Série Zoologia, 100: 319-328.

IUCN Standards and Petitions Subcommittee. 2014. Guidelines for using the IUCN Red List Categories and Criteria. Version 11. Prepared by the Standards and Petitions Subcommittee. Downloadable from http://www.iucnredlist.org/documents/ RedListGuidelines.pdf. (03 May 2016).

Lima, F. C. T., L. R. Malabarba, P. A. Buckup, J. F. Pezzi da Silva, R. P. Vari, A. Harold, R. Benine, O. T. Oyakawa, C. S. Pavanelli, N. A. Menezes, C. A. S. Lucena, M. C. S. L. Malabarba, Z. M. S. Lucena, R. E. Reis, F. Langeani, L. Cassati, V. A. Bertaco, C. Moreira \& P. H. F. Lucinda. 2003. Genera incertae sedis in Characidae. Pp. 106-169. In: Reis, R. E., S. O. Kullander \& C. J. Ferraris, Jr. (Orgs.). Check list of the freshwater fishes of South and Central America. Porto Alegre, Edipucrs.

Lima, F. C. T., T. H. S. Pires, W. M. Ohara, F. C. Jerep, F. R. Carvalho, M. M. F. Marinho \& J. Zuanon. 2013. Characidae. Pp. 213-395. In: Queiroz, L. J., G. Torrente-Vilara, W. M. Ohara, T. H. S. Pires, J. Zuanon \& C. R. C. Dória (Orgs.). Peixes do rio Madeira. 1 ed. São Paulo, Dialeto Latin American Documentary, v.1.

Malabarba, L. R. 1998. Monophyly of the Cheirodontinae, characters and major clades (Ostariophysi: Characidae). Pp. 193-233. In: Malabarba, L. R., R. E. Reis, R. P. Vari, Z. M. S. Lucena \& C. A. S. Lucena (Orgs.). Phylogeny and classification of Neotropical fishes. Porto Alegre, Edipucrs.
Maldonado-Ocampo, J. A., R. P. Vari \& J. S. Usma. 2008. Checklist of the freshwater fishes of Colombia. Biota Colombiana, 9:143-237.

Mariguela, T. C., G. Ortí, G. S. Avelino, K. T. Abe \& C. Oliveira. 2013. Composition and interrelationships of a large Neotropical freshwater fish group, the subfamily Cheirodontinae (Characiformes: Characidae): a case study based on mitochondrial and nuclear DNA sequences. Molecular Phylogenetics and Evolution, 68: 23-34.

Mirande, J. M. 2010. Phylogeny of the family Characidae (Teleostei: Characiformes): from characters to taxonomy. Neotropical Ichthyology, 8: 385-568.

Oliveira, C., G. S. Avelino, K. T. Abe, T. C. Mariguela, R. C. Benine, G. Ortí, R. P. Vari \& R. M. C. Castro. 2011. Phylogenetic relationships within the speciose family Characidae (Teleostei: Ostariophysi: Characiformes) based on multilocus analysis and extensive ingroup sampling. BMC Evolutionary Biology, 11: 275(25p.).

Ortega, H., M. Hidalgo, E. Correa, J. Espino, L. Chocano, G. Trevejo, V. Meza, A. M. Cortijo \& R. Quispe. 2010. Lista anotada de los peces de aguas continentales del Perú: estado actual del conocimiento, distribución, usos y aspectos de conservación 1 ed. Lima, Peru, Ministerio del Ambiente, Dirección General de Diversidad Biológica, Museo de Historia Natural/UNMSM.

Sabaj Pérez, M. H. 2014. Standard symbolic codes for institutional resource collections in herpetology and ichthyology. Version 5.0 (22 September 2014). American Society of Ichthyologists and Herpetologists. Availabe from: http://www.asih.org. (28 January 2016).

Tagliacollo, V. A., R. Souza-Lima, R. C. Benine \& C. Oliveira. 2012. Molecular phylogeny of Aphyocharacinae (Characiformes, Characidae) with morphological diagnoses for the subfamily and recognized genera. Molecular Phylogenetics and Evolution, 64: 297-307.

Vari, R. P. 1978. The genus Leptagoniates (Pisces: Characoidei) with a description of a new species from Bolivia. Proceedings of the Biological Society of Washington, 91: 184-190.

Submitted September 28, 2015 Accepted February 08, 2016 by Fernando Carvalho 